IJLR: International Journal of Law Recontruction

Volume 5, Number 1, April 2021

DOI : http://dx.doi.org/10.26532/ijlr.v5i1.15484

\title{
ONLINE CREDIT AGREEMENT WITH COLLATERAL IN INDONESIA
}

\author{
Ma'ruf Akib \\ Muhamadiyah University of Kendari \\ maeroef@gmail.com
}

\begin{abstract}
Along with the rapid development of information technology which in turn has an impact on economic activity around the world, financial technology is here to provide facilities in the provision of financial services for the community. The ease of convenience offered through unsecured online loans carries the risk of loan defaults made by debtors. The purpose of this research is to find out what is the urgency of the need for collateral as one of the requirements for submitting online loans and how online registration of fiduciary collaterals can be a preventive measure for bad credit in online credit distribution. This study uses a normative-juridical research method. The result of this research is that there is a collateral that the online lending agreement functions as a legal umbrella so that debtors' obligations to creditors are fulfilled so that they avoid default, default, and even investor losses in Fintech P2P Lending activities. The importance of having a fiduciary collateral that is registered in the credit agreement online is to avoid a legal vacuum (rechts vacuum) or legal vacuum (wet vacuum) when there is default or default by the debtor.
\end{abstract}

Keywords: Agreement, Collateral, Online Credit.

\section{A. INTRODUCTION}

Information technology, which is rapidly developing, has an impact on economic activity around the world. ${ }^{1}$ The economic ecosystem in Indonesia is no exception. The Indonesian banking sector has a function as community empowerment and all national economic strengths. ${ }^{2}$ As one of the agents of national development, the banking sector, through its financial institutions, is obliged to keep abreast of existing technological developments so as to create new opportunities for the realization of a more productive economic pace. ${ }^{3}$

Along with this, financial institutions in Indonesia are starting to adapt to digital technology in the implementation of economic activities. From here the term Financial Technology was born. Fintech is the application and utilization of technology to improve banking and financial

1 Mariske Myeke Tampi, Menakar Progresivitas Teknologi Finansial (Fintech) Dalam Hukum Bisnis Di Indonesia, Era Hukum: Jurnal Ilmiah Ilmu Hukum, Volume 16 No. 2, October 2018, page. 247

2 Rifka Regar, William A. Areros, Joula J. Rogahang, Analisis Pemberian Kredit Mikro Terhadap Peningkatan Nasabah Studi Pada Pt. Bank Sulutgo Cabang Manado, Jurnal Administrasi Bisnis Universitas Sam Ratulangi Manado, Volume 4 No. 4, 2016. page. 2

3 Ibid. 
services that are generally carried out by startup companies by utilizing software technology, in this case, applications on smart phone devices. ${ }^{4}$

The presence of financial companies in online loan services is increasingly getting public attention. The financial service that fintech offers is peer to peer lending (P2P Lending). The Financial Services Authority (hereinafter referred to as $\mathrm{OJK}$ ) and Bank Indonesia are the regulators for these services. This is stated in the Financial Services Authority Regulation Number 77 / PJOK.01.2016 concerning Online-Based Money Lending Services. ${ }^{5}$ The POJK regulates peer to peer money lending and borrowing services. This service is a breakthrough for Indonesians who do not know about banking services but who already understand technology. P2P Lending-based fintech services are one of the solutions to limited access to financial services in Indonesia and realize financial inclusion through synergies with other financial institutions and technology companies. ${ }^{6}$

Currently, many P2P lending service providers offer unsecured loans with various loan interest rates. The lending rate at fintech P2P Lending ranges from $3 \%-5 \%$. With a repayment period of up to 12 months. Nevertheless, enthusiasts of this service users continue to increase from year to year. According to OJK data, the amount of disbursement of funds from online lending activities itself grew by 18.32 percent and 134.59 percent per year. ${ }^{7}$ This data shows that the need for online financial services continues to be in demand. The ease of convenience offered through online loans without collateral does not mean it does not save legal problems going forward. One of the risks of this service is the occurrence of loan defaults by the debtor. This of course has a negative impact on both parties, creditors and debtors. Therefore, it is necessary to collateral legal certainty that loan funds are not constrained by bad credit.

Collateral is the basis for creditors to disburse credit to debtors. The existence of a collateral can provide peace to creditors in the credit agreement process. ${ }^{8}$ The term collateral comes from the word zekerheid or cautie, which is the debtor's ability to pay off his debt or obligation to the creditor by holding certain objects that have economic value or have a selling value as a collateral for loans or debts received by the debtor against his creditors. ${ }^{9}$ However, until now the OJK in its regulations issued, POJK 77

4 Dwi Fidhayanti, Pengawasan Bank Indonesia Atas Kerahasiaan Dan Keamanan Data/ Informasi Konsumen Finansial Technology Pada Sektor Mobile Payment, Jurisdictie: Jurnal Hukum dan Syariah, Volume 11 No. 1, Juni 2020, page. 21

5 Widhi Ariyo Bimo dan Alvin Tiyansyah, Peran Otoritas Jasa Keuangan Dalam Mengawasi Pinjaman Berbasis Teknologi Informasi (Fintech Lending), Moneter, Volume 7 Number 01, April 2019. page. 31-32

6 Ninis Nugraheni, Qonitah Annur Aziza, The Existence Of Collateral In Credit Through PeerTo-Peer Lending Services, Yustisia, Volume 9 Number 1, Januari- April 2020. page. 101102

7 https://www.liputan6.com/bisnis/read/4502202/ojk-catat-jumlah-nasabah-pinjaman-onlinetumbuh-13459-persen-di-desember-2020 accessed on February 2, 2021 at 20.00 WIB.

8 Dhanty Ayudita Golonda, Fungsi Jaminan Dalam Pelaksanaan Pemberian Kredit Berdasarkan Uu No. 4 Tahun 1996 Tentang Hak Tanggungan, Lex Privatum, Volume 05 Number 07, September 2017. page. 78 
of 2016 explains that P2P Lending companies can only act as a mediator or creditor agent. Until now, the use of collateral or collateral as a condition of credit or loan can only be done by the bank, where the creditor and the debtor meet to enter into a credit agreement using certain collaterals.

This study aims to determine how urgency is the need for collateral as one of the requirements for applying for online loans and how online registration of fiduciary collaterals is a preventive measure for bad credit in online credit distribution.

\section{B. RESEARCH METHODS}

This study uses a normative-juridical research method. The normative-juridical research method is literature law research which is carried out by examining library materials or secondary data. ${ }^{10}$ This research was conducted in order to obtain materials in the form of: theories, concepts, legal principles and legal regulations related to the subject matter. ${ }^{11}$

\section{RESULT AND DISCUSSION}

\section{The Urgency of Collateral in the Online Loan Credit Agreement.}

Collateral or zekerheid or cautie in Dutch, covers in general the ways the creditor collaterals the fulfillment of the bill, in addition to the general liability of the debtor for his goods. Apart from the term collateral, it is also known as collateral. In Act Number 7 of 1992 concerning Banking, the definition of collateral is an additional collateral that is given by the debtor customer to the bank in order to obtain a credit facility.

Collateral functions to ensure the fulfillment of obligations that can be valued in money arising from a legal engagement. ${ }^{12}$ Collateral is related to the law of property, collateral is used to create confidence that the debtor will fulfill his obligations. In other words, the collateral focuses on the realization of the fulfillment of obligations to the creditor, the form of the collateral can be valued in money, and the collateral arises because of the engagement between the creditor and the debtor.

The term collateral has been commonly used in an engagement between a debtor and creditor because in the science of law scientific terms such as collateral law, material security, individual collateral, collateral rights, etc., are also used in statutory regulations. namely laws such as the Mortgage Rights Law and fiduciary security. Regulations regarding collaterals can be found in Book II of the Civil Code and Stb. 1908 Number 542 as amended to Stb. 1937 Number 190 concerning Credietverband. In Book II of the Civil Code, the legal provisions relating to collateral law are fiduciary and mortgage. Fiduciary is regulated in

10 Theresia Anita Christiani, Normative and Empirical Research Method: Their Usefulness and Relevance in the Study of Law as an Object, 3rd Global Conference on Bussiness and Social Science, December 2015, page. 203

11 Ibid.,

12 Tan Kamelo, Hukum Jaminan Fidusia, Alumni, Bandung, 2004, page. 2 
Article 1150 of the Civil Code to Article 1160 of the Civil Code, while mortgages are regulated in Article 1162 to Article 1232 of the Civil Code.

Until now, there have been many legal provisions regarding collaterals passed in the law. In the pre-reform era, the legal provisions governing collaterals were Law Number 5 of 1960 concerning Basic Agrarian Principles. This provision also refers to various other laws and regulations. This can be seen in the preamble of Law Number 5 of 1960 which revokes the entry into force of Book II of the Indonesian Civil Code regarding the earth, water, and natural resources contained therein, except for the provisions regarding the hypotheek which are still in effect since the enactment of this law. . Even though during the independence era until now, our government has enacted many laws related to collaterals, but we still apply the legal provisions listed in Book II of the Civil Code.

The legal provisions that are still in effect in Book II of the Civil Code are those related to pawning (pand) and mortgages, especially those relating to the imposition of mortgages for ships weighing $20 \mathrm{~m} 3$ and aircraft. While matters relating to land rights apply the legal provisions listed in Law Number 4 of 1996 concerning Mortgage Rights. And in the reform era, Law Number 42 Year 1999 regarding Fiduciary Collateral has also been enacted.

The scope of the legal review of collaterals includes general collaterals and special collaterals. Special collaterals are divided into two (2) types, namely: ${ }^{13}$

a. Individual collateral.

Individual security rights arise from a collateral agreement between the creditor (bank) and a third party. An individual collateral agreement is a relative right, that is, a right that can only be maintained against certain people who are bound in the agreement. ${ }^{14}$

b. Material Collateral.

Material security is an absolute (absolute) right to a certain object that is the object of collateral for a debt, which at one time can be cashed for the repayment of debtor's debt if the debtor breaks his promise. By having various advantages, namely the characteristics it has, including absolute nature in which everyone must respect this right, having a droit de preference, droit de suite, as well as the principles contained therein, such as the principle of speciality and publicity which has given the position and privileges for the right holder / creditor, so that in practice the creditor is preferable to individual collaterals. ${ }^{15}$

13 Niken Praseyowati, Tony Hanoraga, Jaminan Kebendaan Dan Jaminan Perorangan Sebagai Upaya Perlindungan Hukum Bagi Pemilik Piutang, Jurnal Sosial Humaniora, Volume 8 Number 01, Juni 2015. page. 120-121

14 Djuhaendah Hasan dan Salmidjas Salam, Aspek Hukum Hak Jaminan Perorangan dan Kebendaan, Jakarta, 2000, page. 210

15 Ibid. page. 214 

namely: ${ }^{16}$

As for the collateral law, there are five important principles known,

a. The principle of publicity, namely the principle that all rights, both liability rights, fiduciary rights, and mortgage rights must be registered. This registration is intended so that the third party can find out that the collateral object is being imposed with collateral. Registration of mortgage rights at the registration office at the Regency / City National Land Agency office, fiduciary registration is carried out at the fiduciary registration office at the Ministry of Justice and Human Rights office, while marine mortgage registration is carried out in front of registrant officials and registrar of name, namely harbormaster.

b. The principle of specialty, namely that mortgage rights, fiduciary rights and mortgages can only be charged on parcels or on goods that have been registered under the name of a certain person.

c. The principle of indivisibility, namely the principle that debt can be divided cannot result in sharing of mortgage, fiduciary, mortgage, and liens even though partial payments have been made.

d. The principle of inbezittstelling, namely the collateral (pawning) must be with the recipient of the pledge.

e. Horizontal principle, namely the building and land are not a single unit. This can be seen in the use of use rights, both state land and property rights. The building belongs to the person concerned or the dependent provider, but the land belongs to someone else, based on the right to use.

In a credit agreement with a bank, collateral is used as one of the conditions in the filing. This can serve as a step in an economic and legal assessment to determine whether a debtor deserves the trust of a bank to use bank loanMeanwhile, as mentioned earlier, Fintech P2P lending operators may not act as banks. Fintech P2P lending organizers only act as a mediator for lending funders, most of which also come from fintech consumers who invest their personal funds in the hope of getting a profit from the amount of loan interest or according to the benefits agreed between Fintech P2P Lending organizers and loan funders funds.

Meanwhile, as mentioned earlier, Fintech P2P lending operators may not act as banks. Fintech P2P lending organizers only act as a mediator for lending funders, most of which also come from fintech consumers who invest their personal funds in the hope of getting a profit from the amount of loan interest or according to the benefits agreed between Fintech P2P Lending organizers and loan funders. ${ }^{17}$

Although the OJK as an independent financial services sector

16 Juliana Evawati, Asas Publisitas Pada Hak Jaminan Atas Resi Gudang, Yuridika, volume 29 Nomor 02, Mei 2014, page.237

17 Rinitami Njatrijani, Perkembangan Regulasi Dan Pengawasan Finansial Technologydi Indonesia, Diponegoro Private Law Review, Volume 4 Number 01, February 2019. page. $465-466$ 
supervisory agency has issued various integrated regulatory and supervisory systems, the provision of credit through Fintech Peer to Peer Lending has many problems in practice. ${ }^{18}$ The implementation of lending and borrowing activities is carried out by the parties without meeting face to face. This has created loopholes for the fraudulent use of the data and information provided, such as the amount of income of the prospective debtor, which affects the risk factor assessment that should be carried out by the creditor together. As a result, there is a subjective analysis of the risk of default. In addition, there are many cases where creditors find it difficult to collect payments because the residential address listed does not match the real conditions in the field.

In addition, online accounts payable activities without using collateral also carry a risk for debtors. Debtors will find it difficult to adjust their ability to pay because of the easy procedures for submitting online forests without collateral. This also results in the debtor's weak awareness of interest and the amount of fines imposed in the event of default. The amount of debt that must be paid continues to accumulate, which then exceeds the debtor's ability to pay. Many cases of debtors who experience default suffer losses not only from a financial point of view but also affect the debtor's quality of life. ${ }^{19}$ For investors, debt activity or credit disbursement without collateral also has a negative impact on their investment assets. If creditors are in arrears, the risk of loss and even forfeiting of funds must be borne by the investor. However, investors need to understand the risk of credit activity without collateral or collateral in a comprehensive manner. ${ }^{20}$

These risks illustrate the importance of a collateral in an online credit agreement. This is especially true if the amount of funds given to debtors is large. In this case a collateral in the form of fiduciary has the benefit of being a safe way of providing credit facilities. Especially if there is a case of default to default by the debtor. This also has an impact on the interests of investors who will get a collateral of the safety of the funds that have been invested so that they can avoid losses.

\section{Registration of Fiduciary Collateral Online as a Preventive Action for Bad Credit in Online Loans.}

History records that fiduciary security has been used as a form of collateral since the Dutch era, following the jurisprudence in the Roman era. At that time fiduciary collaterals did not require registration in practice. This raises several problems, namely the presence of legal uncertainty and unfulfilled elements of publicity. Therefore, Article 11 of the Fiduciary Security Law requires fiduciary registration for objects

18 Titik Wijayanti, Pelaksanaan pemberian Kredit Berbasis Teknologi Informasi oleh Fintecg Kepada pelaku UKM (studi pengawasan OJK Surakarta), University of Muhammadiyah Surakarta Thesis Publication Manuscript, Agustus 2018. page.14-16

19 https://financer.com/id/blog/pengalaman-tidak-membayar-pinjaman-online/ accessed on February 2, 2021 at 22.00 WIB.

20 Titik wijayanti, Op.cit. page.16 
bearing collateral. ${ }^{21}$

At present, with the development of Fintech technology through its P2P lending service, registration of fiduciary collaterals can be done through an online system. Online fiduciary registration can be a preventive step in preventing defaults and bad credit in online lending activities through Fintech P2P Lending. Online fiduciary registration is different from manual recording systems. If the manual system of recording is carried out by an authorized official for this, the online system of registration is carried out by inputting data on the online system. ${ }^{22}$

One example of a P2P lending service provider that uses collateral is Akseleran. According to the data provided on the official website, $98 \%$ of the loan portfolio value uses collateral. Most of the collateral used is an invoice registered with a fiduciary institution. ${ }^{23}$

Online collateral registration is regulated in the Regulation of the Minister of Law and Human Rights Number 10 of 2013 concerning Electronic Fiduciary Registration Procedures in article 2 which states as follows: ${ }^{24}$

a. Applications for Electronic Fiduciary Registration are submitted to the Minister.

b. Fiduciary Security Registration as intended in paragraph (1) includes:

1) registration of application for Fiduciary Security;

2) registration of changes to the Fiduciary Collateral; and

3) Abolition of Fiduciary Collateral.

Meanwhile, Article 3 stipulates the provisions regarding the procedure for registering an application for fiduciary security electronically. Registration is done by accessing the website www.sisminbakum.go.id . to register the fiduciary collateral deed. Online registration of the Fiduciary Application is done by filling out the application form. The filling out of the form includes the identity of the applicant, the identity of the fiduciary, the deed of fiduciary security, principal agreement, collateral value and other values that are the object of the Fiduciary Collateral. After that the applicant prints proof of registration after completing filling out the application form.

Proof of Registration must contain the registration number, date of filling in the application, the name of the applicant, the name of the

21 Ibid.

22 Gretel Marlene Yola Sianipar, Aju Putrijanti, Irma Cahyaningtyas, Pelaksanaan Tugas Kantor Pendaftaran Fidusia Terhadap Pemberlakuan Sistem Administrasi Pendaftaran Jaminan Fidusia Secara Elektronik Di Provinsi daerah Istimewa Yogyakarta, Notarius, Volume 13 Number 1, Januari 2020, page. 390

23 https://www.akseleran.co.id/blog/risiko-pendanaan-p2p-lending-cara-mengatasinya/\# accessed on February 2, 2021 at 22.30 WIB.

24 Regulation of the Minister of Law and Human Rights Number 10 of 2013 concerning Electronic Fiduciary Registration Procedures, accessed via http://www.bphn.go.id/data/documents/13pmkumham010.pdf on February 2, 2021 at 22.35 WIB 
Fiduciary Registration office, the type of application and the registration fee for the application in accordance with the provisions of laws and regulations.. Payment of fiduciary security registration fees is made through the Perception Bank. After that the applicant prints a fiduciary security certificate that has been signed electronically by the Fiduciary Security Registration Officer.

The birth of a fiduciary collateral through an online system is the same as a manual system, namely when the fiduciary collateral is recorded. Fiduciary Collateral, born on the same date as the date the fiduciary security was recorded in the online system. ${ }^{25}$ This online collateral registration has good benefits for parties involved in Fintech P2P Lending, namely having the right to precede (preference). The position of preference relates to the outcome of execution, this is clear when it is related to Article 1132 BW, which in principle, creditors share the results of the execution of assets belonging to the debtor, with the imposition of fiduciary collaterals, creditors become preference for the proceeds from the sale of certain assets belonging to the debtor, and he has the right to take in advance the money from the execution of the fiduciary object. In addition, the fiduciary security that is registered online still has the same executorial power as the manual fiduciary registration.

The execution of the fiduciary collateral object can be carried out based on the grosse fiduciary collateral certificate in accordance with the provisions of Article 29 paragraph (1) sub a of the Fiduciary Collateral Law or with the executorial title of the fiduciary collateral certificate given by Article 15 a yat (2) of the Fiduciary Collateral Law. The fiduciary collateral certificate has the same executorial power as a court decision that has permanent legal force, so the execution of the fiduciary collateral object is based on the grosse fiduciary collateral certificate or with the executorial title of the fiduciary collateral certificate following the implementation of a court decision. On this basis, the fiduciary automatically can execute the object which is used as the object of fiduciary security if the debtor or fiduciary fails to promise, without having to wait for a warrant (decision) from the court.

Based on OJK database, the default rate on online loans or through fintech P2P Lending in 2020 increased to 8.2 percent. This significant figure occurs because of the inability of customers to pay off their loan debts due to the economic impact of the Covid 19 outbreak. This should have been avoided if only Fintech P2P Lending service providers collaborated with banks or fiduciary security agencies such as what was done by PT. Julo Teknologi Finansial (hereinafter only referred to as PT. Julo) which collaborated with PT. BFI Finance Indonesia Tbk (hereinafter only referred to as PT. BFI) as a financing institution with fiduciary collaterals.

Prospective Debtors of PT. Julo, who chose a loan with a fiduciary collateral (BPKB vehicle or land ownership deed), then made a fiduciary 
bond with PT. Julo through PT. BFI This procedure is carried out by the creditor conducting a physical inspection of the goods to be collaterald to verify the quality and quantity of the goods and the specifications of the goods (for BPK motorized vehicles), receipts or invoices or certificates (if the collateral is in the form of a land certificate). ${ }^{26}$ After the creditor is sure of the accuracy of the collateral data and the correctness of ownership of the goods, then the credit agreement is made in front of a notary appointed by PT. BFI. Creditors and debtors meet face to face in making credit agreements. ${ }^{27}$

Even though in its implementation this reduces the practical value of what is the goal of implementing Fintech P2P Lending-based loans, this step ensures the safety of both debtors and creditors so as to avoid the impact of not registering fiduciary collaterals and even the impact of default and default payments at a later date. The consequences that arise if the collateral is not registered (or even without the collateral) include, among others, the creditor does not have a position as the preferred creditor and if he receives fiduciary it will be difficult to execute it. In addition, there may be intentional action on the part of parties (especially debtors) to delay payment of bills until defaults occur to default.

In the absence of collateral (including those that are registered) in the P2P Lending fintech loan process, a legal vacuum (rechts vacuum) or legal vacuum (wet vacuum) can arise in the event of default or default by the debtor. ${ }^{28}$ This happens because there are no specific regulations governing dispute resolution in the event of default or default on P2P Lending Fintech loans. Until now, Indonesia only has regulations that regulate in general about dispute resolution on Fintech P2P Lending activities. OJK Regulation Number 77 / POJK.01 / 2016 does not explain the settlement in the event of a dispute. Article 21 of the POJK only states that operators and users must mitigate risks. This means that the organizer must be able to ensure efforts to reduce the possibility of the occurrence or risk impact of the default.

\section{CONCLUSION}

Lending activities online without collateral save a lot of problems, among others, there is a gap in the fraudulent information provided by prospective debtors to P2P Lending Fintech organizers, such as the amount of income of prospective debtors, where this is risk mitigation. In addition, the debtor will have difficulty adjusting the ability to pay because of the easy procedure for applying for credit online without such collateral. This also results in the debtor's weak awareness of interest and the amount of

26 Andri Winjaya Laksana, Nur Khasanah, Juridical Review Of The Implementation Of Unsecured Loans On Finansial Technology, Unissula, The 2nd Internasional Conference and Call Paper, Volume 1 No. 1 September 2020, page. 258

27 Ibid.

28 Theresia Tri Utami, Rechtvakum Dalam Penyelesaian Pinjaman Gagal Bayar Pada Pinjaman Online Di Indonesia, Jurnal Rechtsvinding, April 2020, page.5 accessed via https://rechtsvinding.bphn.go.id/?page $=$ artikel\&berita $=297$ 
fines imposed in the event of default. For investors, providing loans without collateral will have a negative impact on their investment assets in case of default or default. Online collateral registration has good benefits for parties involved in Fintech P2P Lending, namely creditors have the right to precede (preference) in exercising their rights to goods that are used as objects of collateral. The importance of having a fiduciary collateral that is registered in the online credit agreement is to avoid a legal vacuum (rechts vacuum) or legal vacuum (wet vacuum) in the event of default or default by the debtor. This is because there are no specific regulations governing dispute resolution in the event of default or default on P2P Lending Fintech loans.

\section{BIBLIOGRAPHY}

\section{Books:}

Djuhaendah Hasan dan Salmidjas Salam, 2000, Aspek Hukum Hak Jaminan Perorangan dan Kebendaan, Jakarta.

Salim HS, H, S.H., M.S., 2011, Perkembangan Hukum Jaminan di Indonesia, Cet.V, PT.Raja Grafindo Persada, Jakarta.

Tan Kamelo, 2004, Hukum Jaminan Fidusia, Alumni, Bandung.

\section{Journals}

Andri Winjaya Laksana, Nur Khasanah, Juridical Review Of The Implementation

Of Unsecured Loans On Finansial Technology, Unissula, The 2nd

Internasional Conference and Call Paper, Volume 1 Number 1 September 2020.

Dhanty Ayudita Golonda, Fungsi Jaminan Dalam Pelaksanaan Pemberian Kredit Berdasarkan Uu No. 4 Tahun 1996 Tentang Hak Tanggungan, Lex Privatum, Volume 05 Number 07, September 2017.

Dwi Fidhayanti, Pengawasan Bank Indonesia Atas Kerahasiaan Dan Keamanan Data/ Informasi Konsumen Finansial Technology Pada Sektor Mobile Payment, Jurisdictie: Jurnal Hukum dan Syariah, Volume 11 Number 1, June 2020.

Gretel Marlene Yola Sianipar, Aju Putrijanti, Irma Cahyaningtyas, Pelaksanaan Tugas Kantor Pendaftaran Fidusia Terhadap Pemberlakuan Sistem Administrasi Pendaftaran Jaminan Fidusia Secara Elektronik Di Provinsi daerah Istimewa Yogyakarta, Notarius, Volume 13 Number 1, Januari 2020.

Ida Ayu Made Widyari, I Nyoman Sirtha, I made Sarjana, Akibat Hukum

Pendaftara Jaminan Fidusia Dalam Sistem Online, Acta Comitax, Volume 2 Number 2 August 2017.

Juliana Evawati, Asas Publisitas Pada Hak Jaminan Atas Resi Gudang, Yuridika, Volume 29 Number 02, May 2014. 
Mariske Myeke Tampi, Menakar Progresivitas Teknologi Finansial (Fintech) Dalam Hukum Bisnis Di Indonesia, Era Hukum: Jurnal Ilmiah IImu Hukum, Volume 16 Number 2, October 2018.

Niken Praseyowati, Tony Hanoraga, Jaminan Kebendaan Dan Jaminan Perorangan Sebagai Upaya Perlindungan Hukum Bagi Pemilik Piutang, Jurnal Sosial Humaniora, Volume 8 Number 01, Juni 2015.

Ninis Nugraheni, Qonitah Annur Aziza, The Existence Of Collateral In Credit Through Peer-To-Peer Lending Services, Yustisia, Volume 9 Number 1, Januari- April 2020.

Rifka Regar, William A. Areros, Joula J. Rogahang, Analisis Pemberian Kredit Mikro Terhadap Peningkatan Nasabah Studi Pada Pt. Bank Sulutgo Cabang Manado, Jurnal Administrasi Bisnis Universitas Sam Ratulangi Manado, Volume 4 Number 4, 2016.

Rinitami Njatrijani, Perkembangan Regulasi Dan Pengawasan Finansial Technologydi Indonesia, Diponegoro Private Law Review, volume 4 Number 01, February 2019.

Theresia Anita Christiani, Normative and Empirical Research Method: Their Usefulness and Relevance in the Study of Law as an Object, 3rd Global Conference on Bussiness and Social Science, December 2015.

Theresia Tri Utami, Rechtvakum Dalam Penyelesaian Pinjaman Gagal Bayar Pada Pinjaman Online Di Indonesia, Jurnal Rechtsvinding, April 2020.

Titik Wijayanti, Pelaksanaan pemberian Kredit Berbasis Teknologi Informasi oleh Fintecg Kepada pelaku UKM (studi pengawasan OJK Surakarta), University of Muhammadiyah Surakarta Thesis Publication Manuscript, August 2018.

Widhi Ariyo Bimo dan Alvin Tiyansyah, Peran Otoritas Jasa Keuangan Dalam Mengawasi Pinjaman Berbasis Teknologi Informasi (Fintech Lending), Moneter, Volume 7 Number 01, April 2019

\section{Legislation}

Financial Services Authority Regulation Number 77 / Pojk.01/2016 concerning Information Technology-Based Borrowing and Lending Servicesi.

Regulation of the Minister of Law and Human Rights Number 10 of 2013 concerning Electronic Fiduciary Registration Procedures.

\section{Websites}

https://financer.com/id/blog/pengalaman-tidak-membayar-pinjaman-online/

https://rechtsvinding.bphn.go.id/view/view online.php?id=305

https://www.akseleran.co.id/blog/risiko-pendanaan-p2p-lending-caramengatasinya/ 
http://www.bphn.go.id/data/documents/13pmkumham010.pdf

https://www.liputan6.com/bisnis/read/4502202/ojk-catat-jumlah-nasabahpinjaman-online-tumbuh-13459-persen-di-desember-2020 